\title{
ACQUIRING EU FUNDS FOR THE DEVELOPMENT OF RESEARCH POTENTIAL OF ENTERPRISES AS A METHOD FOR DEVELOPING SMART SPECIALISATIONS
}

\author{
Witold BIAŁY ${ }^{1 *}$, Jozef ŽARNOVSKÝ 2 \\ ${ }^{1}$ Silesian University of Technology, Institute of Production Engineering, Zabrze, Poland \\ ${ }^{2}$ Slovak University of Agriculture in Nitra, Slovakia
}

\begin{abstract}
Smart specialisations, a new branch of economy/science constituting a new, prospective economical specialisation. It mainly consists in utilising the unique natural resources of a region, connecting various branches, using innovative technological solutions. To successfully increase their research and development potential, enterprises employ funds from the European Union. This article presents a way of successfully utilising EU funds to increase the research and development potential of an enterprise with the example of an automotive company. The authors argue that smart specializations and research and development are important factors of the success of agricultural enterprises as well. The article makes an attempt at analysing the factors which affect the growth of research and development capital of a company and the way in which goals can be achieved. For production companies providing highly processed products (and such companies are also from the agricultural sector) innovation is closely linked to research and development activities. This research and development activity is directed mainly for innovative products, processes, technologies.
\end{abstract}

Keywords: smart specialisations; acquiring funds; EU

In developed economies, a dominating role is played by high technologies, innovative solutions, which is tightly related to the progressing globalisation of economy and wider access to outlets. Only economies based on knowledge will be the beneficiaries of economic growth and development (Záhorská et al., 2016).

The very popular 'innovativeness' (process, product, organisational) is a concept which significantly affects the market and economy (Levesque and Walker, 2007). For production companies which provide highly processed goods, innovativeness is closely connected with research and development activity. This research and development activity is directed mostly at innovative products, processes and technologies.

In this article, the authors touch upon the problem (try to find the answer) of how to efficiently use EU funds in order to increase the research and development potential of an enterprise. The term 'research and development potential of a company' (Warzecha, 2016) is meant to encapsulate such elements as:

- access to scientific and research equipment;

- use of high-tech production methods;

- access to knowledge (patents, know-how);

- staff, the right selection of scientific and technological staff and constantly increasing their knowledge and qualifications (trainings, courses);

- co-operation with universities and scientific and research facilities (knowledge and technology transfers);

- developing the potential of own research infrastructure.

\section{Research and development potential of enterprises}

We understand potential (Podręcznik Oslo, 2008) as the functionality and efficiency of a certain thing, especially an organisation or enterprise, in a given field. Potential is used here as the functionality and efficiency of an enterprise with reference to research and development, which constitutes of the following areas of activity (www.sjp.pwn.pl):

- basic research.

- applied research;

- developmental research.

Research and development (R \& D) (Podręcznik Oslo, 2008) is a term which refers mostly to research work (applied research) as well as the technological preparation of production. $R$ \& $D$ is the first stage of the product's life cycle; it forms its functionality and modernity. In a broader sense, $R \& D$ is a set of actions which take place in all the fields of a company's activity, aimed at achieving profits and taking a strong, competitive position on the market (Stabryła, 2014).

The analysis of the way research potential is increased, which is the subject of this article, is understood as developmental potential. Developmental potential is a technological and production factor, determined mostly through research and development (R \& D). It is scientific and technological advancement as well as the quality development of products, processes and services. Converging here are technological processes (Kłopotek, 2002), which introduce original construction, technical 
and organisational solutions to the company. A property of innovativeness is creating novelty as well as implementing and using it in practice. $R \& D$ activity is closely related to other areas of the company's activity, such as: organisational structures, the economic, personal and informational aspects. It is the criterion used for evaluating the enterprise which indicates the capacity to achieve goals at the level of high efficiency and shows the ability to create added value in research and development activity (R \& D).

Research and development activity incurs costs, which, according to (Nowak and Wierzbiński, 2010; Stabryła, 2014), are the first stage of a product's life. These costs are a sum of components which constitute to the overall cost of the product's life cycle, which, with strategic planning, allows us to estimate the predicted profit from its sale across the product's entire lifespan. When calculating the profit, research and development costs are taken into account, which is often not the case with traditional cost calculations systems.

Developmental capacity of a company depends on its developmental potential and the influence of internal and external factors (forces) which activate its use (OECD, 2013). The influence of internal and external factors on innovative activity of enterprises has been shown in Fig. 1 (Kłopotek, 2002).

In this article, the authors focus on the influence of external factors on the company, which enable (create opportunities for) the development (increasing) of the research and development potential. These forces include funds from the European Union, which companies can acquire for their development. These funds, however, can only be spent on the broadly defined product or process innovations. In the case of large companies, it is required that the innovation must be at least on a nation-wide scale. However, to activate the developmental potential of a company, the external and internal forces must complement each other and be equally taken into account.

In order to be able to effectively and efficiently acquire external funds which support their development, companies should have such internal organisation and structures that the capital acquired can be properly managed and utilised. In a report published in 2015 (Crido Taxand, PAlilZ and techBrainers, 2015), the following have been indicated as the main $R$ \& $D$ activities performer by Polish companies:

- development and introducing new products to the market - indicated by $80 \%$ of the participants;

- patenting inventions - $70 \%$ of respondents;
- developing the employees' initiatives - 50\%;

- scientific research and developing technologies within the company, acceleration and incubation of projects $-30 \%$ of the companies surveyed.

Moreover, the report brings attention to the lack of verification of the effects gained - the only measure used by the respondents is the utilisation of the budget given. It is striking that $55 \%$ of the respondents did not say that they use the Key Performance Indicators (KPIs) (Bujanowska and Biały, 2016) for measurement. There are, however, plans for some form of measurement to be introduced (30\% of those surveyed), such as:

- the newly introduced products' share in overall profits;

- average time of entry to the market from the conception of the idea.

In the report (Crido Taxand, PAlilZ and techBrainers, 2015), R \& D units currently have no precise role in the company's strategy - this problem has been mentioned by $70 \%$ of the respondents. However, as much as $90 \%$ of them indicated that the company's management sees a chance to generate new profits or gain new outlets in the $R \& D$ units. The document setting the priority directions for action in terms of $R$ \& $D$ in Poland is the Economy Innovativeness and Efficiency Strategy 'Dynamic Poland 2020' (Polish Ministry of Economy, 2016). An appendix to the Enterprise Development Programme is the Nationwide Smart Specialisation (NSS), which was developed on the level of the European Union and stems from a strategic approach to economic and technical development through directed support of R \& D (Biały, 2016; Polish Ministry of Economy, 2013; Wolniak and Hąbek, 2016; Molenda, 2016).

\section{Possibilities of increasing the R \& D potential of an enterprise using EU sources}

With the beginning of 2003, the Polish government intensified actions aimed at furthering the completion of the so-called Lisbon Strategy (Żbik, 2012). The next strategy implemented is the 'Strategy for smart, sustainable, inclusive growth', Europe 2020, which is a long-term programme for socio-economic development of the EU for the years 2010-2020 (Komisja Europejska, 2012).

Actions taken by the Polish government resulted in the creation of a National Development Plan for the years 20072013 in 2004, which formulated the tasks for building an economy based on knowledge. The authors of Sosnowska

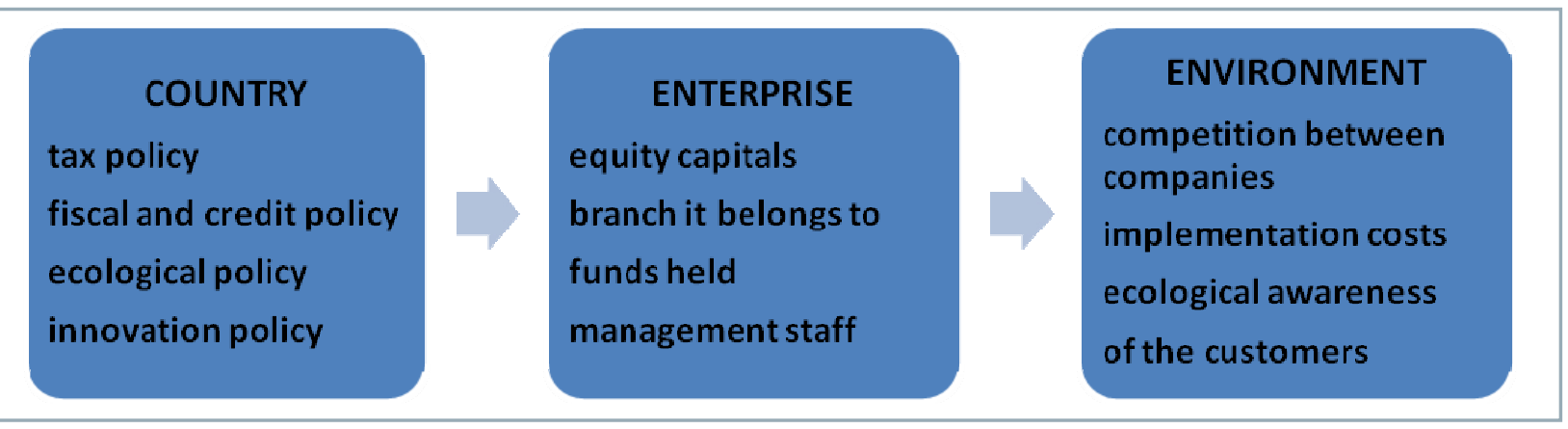

Fig. 1

External and internal factors affecting the innovative activity of enterprises 
et al. (2005) quote various ways of financing innovation funds from the European Union are enumerated as one of the instruments for acquiring external funding sources. Poland (same as every other member state of the EU) can utilise funds from: structural and cohesion fund.

Aid funds given by the EU for the growth of the entire Union are divided centrally by EU institutions or locally (European Commission, 2014). On the level of member states, the funds are distributed through central budgets, local government units or dedicated government institutions. The most important instrument allowing entrepreneurs to co-finance R \& D works with EU funds is the 'Smart growth operational programme for the years 2014-2020' (Komisja Europejska, 2013). The programme consists of many subprogrammes with the following funds:

- Infrastructure and Environment - 27.4 bn Euro;

- Smart Development - 8.6 bn Euro;

- Knowledge, Education, Development - 4.7 bn Euro;

- Digital Poland - 2.2 bn Euro;

- Eastern Poland - 2.0 bn Euro;

- Technical Support - 0.7 bn Euro.

Furthermore, the Rural Development ( 8.5 bn euro) and Sea and Fishing ( 0.5 bn Euro) programmes are also financed with these funds.

Europe-wide and international programmes were also prepared, including:

- European Territorial Cooperation Programme - 0.7 bn Euro;

- European Union Framework Programme:

- Horizon 2020 - 80 bn Euro;
- COSME - 2.3 bn Euro;

- Connecting Europe - 33 bn Euro;

- Erasmus+ - 15 bn Euro;

- Creative Europe - 1.5 bn Euro.

Analysing the above data, we can notice how many financial aid programmes the EU has prepared for its citizens and entrepreneurs; Table 1 shows the sources of enterprise funding for R \& D works (elaboration based on: Warzecha, 2016). The most important programmes include:

- Smart Development;

- Horizon 2020.

The main aim of these actions is to achieve the goals of the Union's horizontal policy 'Strategy for smart, sustainable, inclusive growth', Europe 2020 (Komisja Europejska, 2012). Companies, when presented with the opportunity to support the growth of R \& D activity ought to conduct a comprehensive analysis of needs, which should include:

- Conducting a strategic overview of the company's goals for the nearest future (e.g. 3-5 years);

- Developing strategies for innovative action;

- Defining key developmental goals;

- Defining the potential business partner base;

- Analysis of the actions of the company's direct market competitors (Prístavka et al., 2016).

\section{Development of the R \& D department - Case stady}

The company analysed in this article drastically changed its approach to R \& D works over the last two years. In

Table 1 Sources of funding for R \& D works from EU funds in the years 2015-2020

\begin{tabular}{|c|c|c|c|}
\hline & $\begin{array}{c}\text { Funding for the stage } \\
\text { of research }\end{array}$ & $\begin{array}{l}\text { Implementing R \& D } \\
\text { work results }\end{array}$ & $\begin{array}{c}\text { Creation/expansion } \\
\text { of the CBR }\end{array}$ \\
\hline 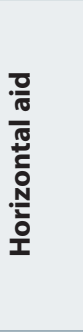 & $\begin{array}{l}\text { - PO IR Axis I: R \& D projects, including Fast } \\
\text { route (1.1.1 PO IR), Demonstrator (1.1.2 PO } \\
\text { IR) and sectorial programmes (1.2 PO IR) } \\
\text { - PO IR Axis IV: Application projects } \\
\text { - Sub-action 4.1.4 } \\
\text { - PRO: R \& D projects } \\
\text { - Strategic NCRD programmes (Strategment, } \\
\text { Biostrateg, Techmastrateg) - research } \\
\text { phase }\end{array}$ & & \\
\hline 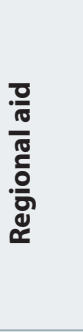 & & $\begin{array}{l}\text { - PO IR Axis III: Aiding innovation in } \\
\text { enterprises/implementing the results of } \\
\text { R \&D works } \\
\text { - PO PW: Implementing innovation by } \\
\text { small and medium-sized enterprises/ } \\
\text { implementing the results of R \& D works } \\
\text { - RPO: Implementing the results of R \& D } \\
\text { works } \\
\text { - SSE }\end{array}$ & $\begin{array}{l}\text { - PO IR: Action } 2.1 \text { Aiding } \\
\text { investments in the } R \text { \& D } \\
\text { infrastructure of enterprises } \\
\text { - Action 4.2 Development of } \\
\text { modern research infrastructure in } \\
\text { the science sector } \\
\text { - RPO: Creation/expansion of CBR - } \\
\text { Special Economic Areas }\end{array}$ \\
\hline 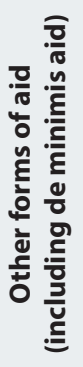 & \multicolumn{3}{|c|}{$\begin{array}{l}\text { - Horizon } 2020 \text { - Small and medium-sized enterprise facility, Fast path to innovation, others } \\
\text { - PO IR: } \\
\text { - Bridge Alfa and Bridge VC (Capital financial instruments) } \\
\text { - Aid for the development of open innovations } \\
\text { - Aid for the protection of the industrial property of enterprises } \\
\text { - Innovation vouchers } \\
\text { - Axis IV: Increasing the scientific and research potential } \\
\text { - Technologytax credit } \\
\text { - Strategic NCRD programmes (Strategment, Biostrateg, Techmastrateg) - preparation for implementation phase } \\
\text { - GO_GLOBAL.PL }\end{array}$} \\
\hline
\end{tabular}


2014, an R \& D department was formed and assimilated into the company's structure, which was formally placed in the Financial Director's department, while substantive supervision is done by the Program Committee (Fig. 2 Warzecha, 2016).

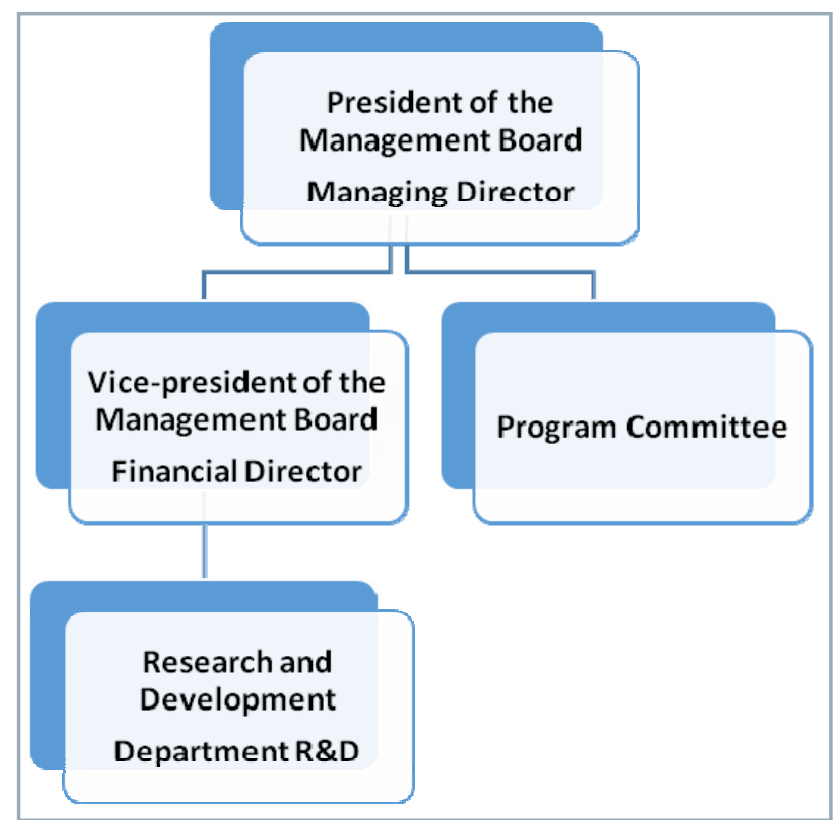

Fig. 2 The R \& D Department within the company's structure

The idea behind the Program Committee is to generate new innovative solutions in the company. In order to streamline the process of cyclical idea generation, employees from various levels, experts and unit managers are sent a table form (Table 2 - Company X, 2016).

That document is used for systematic and standardised data collection that is later verified by the Program Committee. As a result of this procedure, 3 projects co-financed with the EU funds have been approved for implementation over the period of 1.5 years with 3 more currently being examined by the NCRD and the Ministry of Economy.

Project proposals are registered in the so-called idea base, which is an internal knowledge source; stored therein is basic information about idea applications, not only the ones pertaining to products and processes, but also to marketing and organisational ones.

Such a list of projects (innovative ideas) is connected with a larger database containing project sheets and all the executed and 'execution-approved' projects. Access to the database is given to the $R$ \& D department employees as well as certain personnel selected by the Management Board. The database constitutes a source of the company's non-confidential knowledge.

Since the moment the R \& D Department was created, seven financial projects have been, or are being developed, financed with only the company's own funds, as well as three projects co-financed with EU funds in the years 2014, 2015.

During the last five years (2012-2016), the company has experienced very dynamic growth, which has resulted in many prototype solutions being developed.

This shows the dynamic development of the company which also resulted in the creation of the $R \& D$ Department. In the section related to $R \& D$, a decision was made to build a Research and Development Centre, which will be a research base for all the companies of the Capital Group as well as provide R \& D services to external clients. The construction of the RDC was started in 2015; the investment is currently in stage I. The RDC will include objects such as:

- Building A - laboratories;

- Building B - production hall of the prototype workshop; implementation hall;

- Facility C - testing grounds; research laboratory.

An analysis of the company's own experiments and standards developed during the two years of R \& D's

Table 2 Project information sheet

1. Subject of the project

2. Estimated project value

3. Justification - identified market demand, planned results

4. Execution time (in months)

5. Key execution stages - with relations to every stage: execution time, work done, share of stage expenditures in total expenditures, results

6. Human resources engaged in the project - substantive positions

7. Technical resources engaged in the project (as: type - amount - estimated value)

7.1 Machinery/equipment

7.2 Computer stations, printers, etc.

7.3 Consumable materials and resources

7.4 Other

8. Additional (as: type - amount - estimated value)

8.1 Intangible and legal assets (e.g. software, licenses, patents, standards, analyses, research)

8.2 Trainings due to the equipment purchased

8.3 Other

9. Use of industrial design

10. Remarks 


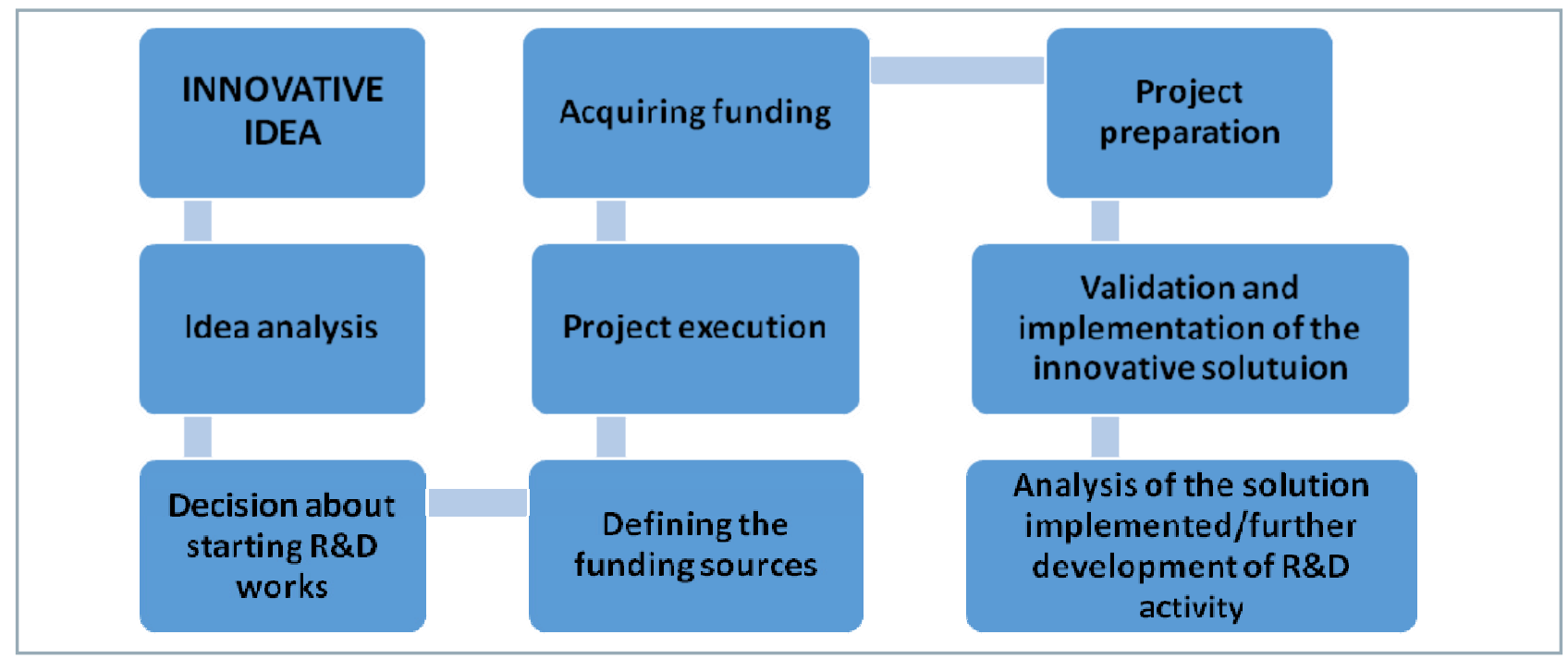

Fig. 3 Stages of R \& D project realisation

functioning in the company allowed for the creation of a model of procedure (Fig. 3) that seems to be optimal in case of taking decisions pertaining to $R \& D$ works being carried out with EU co-funding. It is one of the methods proposed for company development which can bring about tangible benefits and guarantees high efficiency of the actions taken.

Utilising available EU funds significantly reduces the risk of the project's failure. Moreover, executing a project co-financed by the EU forces the company to follow certain procedures, such as:

- reporting;

- scheduling;

- clearance;

- control; external audits.

This method leads to gaining new knowledge and experience in project work, often organisationally connected with other entities, such as: external research facilities, universities, Ministry of the Treasury. Thus, good practices and cooperation with other entities, which is often seen as a source of new ideas, further development, are introduced to the company. Introducing a particular solution to the company ends the whole process, which often entails the protection of property rights (utility models, industrial designs, patents).

The scheme (Fig. 3 - elaboration based on Company $X, 2016)$ shows the stages of realisation of $R \& D$ projects realised with financial aid from the EU. These stages are a synthesis of what has been developed in the company during the last two years of R \& D activity. They constitute a base of procedures and the so-called good practice worked out by the company when realising $\mathrm{R} \& \mathrm{D}$ projects. It is the knowledge developed by the company and based on observation and constant education in the automotive company analysed in the article.

\section{Conclusions}

Conducting research by an enterprise requires consistency, constant supervision and monitoring of progress. Aid provided to enterprises with EU funds for the development of research brings a new quality to the company, enforcing the creation of separate structures, in this case an R \& D department. Through the realisation of innovative projects, a 'new quality' of operation and management as well as new procedures are introduced in production processes. The introduction of a project structure, fulfilling formal requirements connected with the possibility of acquiring funding for the company's R \& D activity leads to the increase of the company's value. Benefits such as: acquiring new knowledge, experience, patents, utility models, industrial designs, are elements directly contributing to the increase of a company's competitiveness.

The increase in R \& D potential is also affected by external and internal factors (which was mentioned earlier). One of the external factors which can be acquired is financial aid offered by the EU. Internal resources, including human resources, have a significant impact on the acquisition of these funds.

This article presented a strategy for acquiring external funds (from the EU) on the example of an automotive company. A certain scheme was developed, which works in case of the company analysed. Aid funds offered by the EU allow companies to accept a higher level of investment risk more easily, as only a part of their own financial and material capital is involved. The EU funds, presented in the paper, open new possibilities for research and development initiatives for agricultural entities as well.

The assumptions of aid programmes include the equalisation of chances between developing economies (which include Poland) and the economies of Western European countries. Financial aid offered to enterprises in order to invest in innovative technologies on a global scale (or at least domestically) should contribute to the increase in their competitiveness on global markets, development of the country's economy, reduction of poverty and unemployment. Sharing similar goals is the Europe 2020 Strategy which envisions supporting smart specialisation of regions, i.e. the innovative development of particular areas of certain countries drawing upon their natural resources, traditional industries, etc., that is all the things which add up to create their specificity and uniqueness. At the same 
time, the cohesion policy of the European Union requires that the evaluation of results of smart specialisation must be based on tangible criteria which enable us to measure the rate and level of development of the regions and thus aim to eliminate the differences that are disadvantageous to their inhabitants. Those criteria also help to evaluate the current state and civilizational advancement of the regions and define the challenges which lie ahead of them in implementation of innovative production, product and process solutions.

\section{Acknowledgements}

The paper is the result of the statutory research project No 13/030/BK_16/0024 entitled 'Production engineering methods and tools for development of smart specializations'.

\section{References}

BIAŁY, W. 2016. The possibilities of production engineering in the development of smart specializations illustrated with the example of the Silesian voivodeship. In Management Systems in Production Engineering, no. 4, p. 252-258. DOI: 10.12914/MSPE-06-04-2016

BUJANOWSKA, A. - BIAŁY, W. 2016. Technical Infrastructure in the Hospital. Assisting Exploitation Processes. Warszawa:Wydawnictwo CeDeWu.

BULLOK, A. - STALYBRASS, O. 1999. Dictionary of Terms Contemporary. Katowice : Wydawnictwo Książnica.

CRIDO TAXAND, PAIIIZ AND TECHBRAINERS. 2015. Market of R + D $+\mathrm{I}$ in Poland. Support of research, development and innovation of enterprises. [Online] Available at: http://techbrainers.com/ prezentacja-raportu-bri-w-polsce-2015

COMPANY X. 2016. Internal company document.

EUROPEAN COMMISSION. 2014. National/regional innovation strategies for smart specialization (RIS3). Cohesion Policy. [Online] Available at: http://ec.europa.eu/regional_policy/sources/ docgener/informat/2014/smart_specialisation_en.pdf

KŁOPOTEK, A. 2002. Pro-innovation policies as a condition of growth of competitiveness enterprises. In Materiały i Prace Instytutu Funkcjonowanie Gospodarki Narodowej, vol. 83, p. 26-36. KOMISJA EUROPEJSKA. 2012. Guide strategy for research and innovation for smart specialization (RIS 3). [Online]. Available at: http://www.poig.2007-2013.gov.pl/2014_2020/Strony/glowna. aspx

KOMISJA EUROPEJSKA. 2013. Commission Regulation (EU) No $1407 / 2013$ of 18 December 2013. on the application of art. 107 and 108 of the Treaty on the Functioning of the European Union to de minimis aid art. 2. paragraph 2 .
KRAŚNICKA, T. 2014. Innovation of contemporary organization. Part. 2. Study and research results. In Zeszyty Naukowe Wydziałowe Uniwersytetu Ekonomicznego w Katowicach. Studia Ekonomiczne, no. 183 , p. 173-184.

LEVESQUE J. - WALKER M. F. 2007. The Innovation Process and Quality Tools. Quality Progress, July.

MOLENDA M. 2016. Risk management as a part of intelligent quality management system in the environmental technology verification body (ETV). In Systemy Wspomagania w Inżynierii Produkcji, no. 4, p. 160-171. Gliwice 2016.

POLISH MINISTRY OF ECONOMY. 2016. National intelligent specialties. [Online]. Available at: http://www.mg.gov.pl/files/ upload/23423/Opisy\%20KIS_wersja\%20finalna_31.03\%202.pdf

POLISH MINISTRY OF ECONOMY. 2013. Strategy for innovation and efficiency of the economy. [Online]. Available at: http://www.kigeit. org.pl/FTP/PRCIP/Literatura/006_1_Strategia_Innowacyjnosci_i_ Efektywnosci_Gospodarki_2020.pdf

NOWAK, E. - WIERZBIŃSKI, M. 2010. Cost Accounting. Models and Applications. Warszawa : Polskie Wydawnictwo Ekonomiczne.

OECD 2013. Innovation-driven growth in regions: The role of smart specialisation. [Online] Available at: https://www.oecd.org/ innovation/inno/smart-specialisation.pdf

PODRĘCZNIK OSLO. 2008. Rules for the collection and interpretation of data on innovation. Warszawa, $3^{\text {rd }}$ ed.

PRÍSTAVKA, M. - KOTOROVÁ, M. - SAVOV, R. 2016. Quality control in production processes. In Acta Technologica Agriculturae, vol. 19, no. 3, p. 77-83.

SOSNOWSKA, A. et al. 2005. How to implement technological innovations in the company. Guide for entrepreneurs. Warszawa : Polska Agencja Rozwoju Przedsiębiorczości.

WARZECHA, R. 2016. A method of increasing the potential of research and development company in the automotive industry with the use of EU funds. (unpublished MS thesis). Zabrze : Wydział Organizacji i Zarządzania.

POLISH LANGUAGE DICTIONARY. 2016. [Online] Available at: http://sjp.pwn.pl

WOLNIAK, R. - HĄBEK, P. 2016. Tools supporting development of smart specialization. In Systemy Wspomagania w Inżynierii Produkcji, no. 4, p. 132-138.

ZÁHORSKÁ, R. - NOZDROVICKÝ, L. - MIKULÁŠIK, L. 2016. Implementation of statistical methods and SWOT analysis for evaluation of metal waste management in engineering company. In Acta Technologica Agriculturae, vol. 19, no. 4, p. 89-95.

ŻBIK, A. 2012. The Lisbon strategy. [Online] Available at: http:// uniaeuropejska.org/strategia-lizbonska 